Jurnal llmu Administrasi Publik 5 (1) (2017): 36-42

Jurnal Administrasi Publik

http://ojs.uma.ac.id/index.php/publikauma

\title{
PENYELESAIAN PERSELISIHAN HUBUNGAN KERJA DI PENGADILAN HUBUNGAN INDUSTRIAL
}

\author{
Maswandi * \\ Fakultas Hukum \\ Universitas Medan Area, Indonesia
}

Diterima Februari 2017, Disetujui April 2017; Dipublikasikan Juni 2017

\begin{abstract}
Abstrak
Hubungan kerja adalah hubungan antara pengusaha antar buruh berdasarkan perjanjian kerja yang mempunyai unsur pekerjaan, upah dan perintah berdasarkan perjanjian kerja antara pekerja dan pengusaha. Pemutusan Hubungan Kerja (PHK) merupakan suatu hal yang pada beberapa tahun yang lalu merupakan suatu kegiatan yang sangat ditakuti oleh karyawan yang masih aktif bekerja. Permasalahan adalah, bagaimana mekanisme penyelesaian perselisihan hubungan industrial dan bagaimana proses hukum penyelesaian perselisihan hubungan kerja di pengadilan hubungan industrial. Perselisihan hubungan kerja terdiri dari perselisihan hak, perselisihan kepentingan dan perselisihan antar serikat pekerja. Perselisihan hubungan kerja pada dasarnya diselesaikan di Pengadilan Perselisihan Hubungan Industrial (Pengadilan $\mathrm{PHI}$ ). Sebelum mencapai tahap atau tingkat Pengadilan PHI dapat menempuh tahap-tahap awal atau alternatife yang terdiri dari: 1. Lembaga Bipartit, 2. Mediasi, 3. Konsilsasi, dan 4. Arbitrase. Dengan cara tersebut, pengadilan memutuskan untuk menghukum pengusaha (tergugat), untuk membayar uang pesangon, uang THR 2013 dan uang pengganti hak yang seharusnya diterima oleh penggugat, sesuai ketentuan Pasal 156 Ayat (1) Undang-Undang Nomor 13 Tahun 2003 Tentang Ketenagakerjaan.
\end{abstract}

Kata Kunci: Pemutusan Hubungan Kerja, Penyelesaian Hubungan Industri.

\begin{abstract}
Employment relationship is a relationship between employers between workers based on employment agreements that have elements of employment, wages and orders based on employment agreements between workers and employers. Termination of Employment (PHK) is a thing that in the past few years is an activity that is feared by employees who are still actively working. The problem is, how is the mechanism of dispute settlement of industrial relations and how the legal process of settlement of labor disputes in industrial relations court. Labor disputes consist of rights disputes, interest disputes and disputes between unions. Labor disputes are essentially settled in the Industrial Relations Disputes Court (PHI Court). Prior to reaching the stage or level of the Court, the IRC can undertake initial or alternate steps consisting of: 1. Bipartite Institution, 2. Mediation, 3. Consilation, and 4. Arbitration. In such a manner, the court decides to punish the employer (defendant), to pay the severance pay, THR of 2013 and compensation rights that should be received by the plaintiff, pursuant to Article 156 Paragraph (I) of Law Number 13 Year 2003 on Manpower.
\end{abstract}

Keywords: Termination of Employment, Settlement of Industrial Relations.

How to Cite : Maswandi, (2017). Penyelesaian Perselisihan Hubungan Kerja di Pengadilan Hubungan Industrial 5 (1): 36-42

$\begin{array}{lr}{ }^{*} \text { Corresponding author: } & \text { P-ISSN-2549-9165 } \\ \text { E-mail: maswandiuma@gmail.com } & \text { e-ISSN -2580-2011 }\end{array}$ 


\section{PENDAHULUAN}

Dalam era industralisasi di atas kemajuan pengetahuan dan teknologi informasi, perselisihan hubungan industrial menjadi semakin kompleks, untuk penyelesaiannya diperlukan institusi yang mendukung mekanisme penyelesaian perselisihan yang cepat, tepat, adil dan murah. UndangUndang Nomor 22 Tahun 1957 tentang Penyelesaian Perburuhan dan Undang-Undang Nomor 12 Tahun 1964 tentang Pemutusan Hubungan Kerja di Perusahaan Swasta sudah tidak sesuai lagi dengan perkermbangan keadaan dan kebutuhan tersebut di atas. Perselisihan hubungan industrial umumnya terjadi karena terdapat ketidaksepahaman dan perbedaan kepentingan antara pelaku usaha dan pekerja.

Dalam Pasal 1 angka 15 Undang-Undang Nomor 13 tahun 2003 Tentang ketenagakerjaan menyebutkan bahwa:

"Hubungan kerja adalah hubungan antara pengusaha antar buruh berdasarkan perjanjian kerja yang mempunyai unsur pekerjaan, upah dan perintah berdasarkan perjanjian kerja antara pekerja dan pengusaha" (Husni, 2004: 63)

Hubungan industrial pada dasarnya adalah suatu hubungan hukum yang dilakukan antara pengusaha dengan pekerja. Dalam hubungan tersebut memang tidak selamanya akan berjalan lancar-lancar saja dalam arti tidak ada permasalahan yang timbul dari hubungan industrial. Ini terbukti dengan banyaknya pemberitaan di media massa saat ini yang memberitakan perselisihan-perselisihan di dalam hubungan industrial tersebut.

Banyaknya faktor yang menjadi penyebab dalam permasalahan atau perselisihan hubungan industrial antara pekerja dan pengusaha, yang antara lain adalah pemutusan hubungan kerja (PHK) atau karena tidak adanya pemenuhan hakhak bagi pekerja. Namun tidak hanya itu, permasalahan hubungan industrial juga bisa terjadi antara para pekerja sendiri. Misalkan antara serikat pekerja dalam saat perusahaan. (Husni, 2004: 41-42)

Karena banyaknya perselisihanperselisihan yang timbul dalam hubungan industrial tersebut, maka perlu dicari cara terbaik dalam menyelesaikan permasalahan atau perselisihan hubungan industrial antara pekerja dengan pengusaha atau pekerja dengan pekerja. Lalu yang menjadi pertanyaan adalah bagaimana menyelesaikan masalah tersebut? Hal ini perlu dikaji secara komprenhensif sehingga dalam hubungan industrial antara pekerja dengan pengusaha tercipta sebuah hubungan yang harmonis dalam upaya mewujudkan suasana ketenagakerjaan yang baik dan harmonis di negeri ini.

Hubungan Industrial pada dasarnya adalah proses terbinanya komunikasi, konsultasi musyawarah serta berunding ditopang oleh kemampuan dan komitmen yang tinggi dari semua elemen yang ada dalam perusahaan. Undang-Undang ketenagakerjaan telah mengatur prinsip-prinsip dasar yang perlu kita kembangkan dalam bidang hubungan industrial. Arahnya adalah untuk menciptakan sistem dan kelembagaan yang ideal, sehingga tercipta kondisi kerja yang produktif, harmonis, dinamis dan berkeadilan.

Sebagai Undang-Undang yang bersifat khusus, Undang-Undang Nomor 2 Tahun 2004 Tentang Penyelesaian Perselisihan Hubungan Industrial memberikan pengertian Arbitrase Hubungan Industrial yang selanjutnya disebut arbitrase adalah penyelesaian suatu perselisihan kepentingan dan perselisihan antarserikat pekerja serikat buruh hanya dalam satu perusahaan, diluar Pengadilan Hubungan Industrial melalui kesepakatan tertulis dari para pihak yang berselisih untuk menyelesaikan perselisihan kepada arbiter yang putusannya mengikat para pihak dan bersifat final.

Sebelum diberlakukan Undang-Undang Nomor 2 Tahun 2004 Tentang Penyelesaian Perselisihan Hubungan Industrial, penyelesaian perselisihan hubungan industrial dilaksanakan berdasarkan Undang-Undang Nomor 22 Tahun 1957 Tentang Penyesuaian Perselisihan Perburuhan dan Undang-Undang Nomor 12 Tahun 1964 Tentang Pemutusan Hubungan Kerja di perusahaan Swasta. Penyelesaian berdasarkan kedua Undang-Undang tersebut ternyata dirasakan sudah tidak sesuai lagi dengan kebutuhan masyarakat, karena tidak dapat lagi mengakomodasi perkembangan yang terjadi terutama mengenai hak-hak para pekerja/buruh. (Mulyadi dan Agus Subroto, 2011: 61). 


\section{PEMBAHASAN}

Perselisihan hubungan kerja terdiri dari perselisihan hak, perselisihan kepentingan dan perselisihan antar serikat pekerja. Perselisihan hubungan kerja pada dasarnya diselesaikan di Pengadilan Perselisihan Hubungan Industrial (Pengadilan PHI). Sebelum mencapai tahap atau tingkat Pengadilan PHI dapat menempuh tahaptahap awal atau alternatife yang terdiri dari: 1 . Lembaga Bipartit, 2. Mediasi, 3. Konsiliasi, dan 4. Arbitrase. (Sudjana, 2005: 12).

Lembaga Bipatrit adalah suatu bentuk perundingan antara pekerja buruh atau serikat buruh dengan pengusaha untuk menyelesaikan perselisihan hubungan kerja. Penyelesaian secara musyawarah ini juga diamanahkan oleh UndangUndang Nomor 13 Tahun 2003 Tentang Ketengakerjaan yaitu Pasal 136 Ayat (1) yang menyebutkan bahwa penyelesaian perselisihan hubungan kerja wajib dilaksanakan oleh pengusaha dan pekerja atau serikat secara musyawarah untuk mufakat. Dan dalam Ayat 2 menyebutkan bahwa dalam hal penyelesaian secara musyawarah untuk mufakat tidak tercapai, maka pengusaha dan pekerja/buruh atau serikat pekerja/serikat buruh menyelesaikan perselisihan hubungan kerja yang diatur dengan undangundang.

Lembaga Bipatrit terdiri dari wakil pengusaha dan wakil pekerja dan atau serikat pekerja. Bila dalam perusahaan belum terbentuk serikat pekerja, wakil pekerja dilembaga Bipatrit dipilih mewakili unit-unit kerja dan atau kelompok profesi. Bila terdapat lebih dari satu serikat pekerja, wakil mereka dilembaga Bipatrit ditetapkan secara proporsional. Walaupun tidak diatur secara khusus dalam undang-undang serikat-serikat pekerja di suatu perusahaan dapat membentuk Forum Komunikasi antara serikat pekerja. Penyeselaian perselisihan antara serikat pekerja dianjurkan dilakukan secara bipartite dalam forum ini bila mereka enggan menyelesaikan di Lembaga bipatrit yang telah ada.

Penyelesaian secara bipartite ini wajib dilaksanakan dan dibuat risalah yang ditanda tangani oleh kedua belah pihak. Proses bipartite harus selesai dalam waktu 30 hari dan jika melewati 30 hari salah satu pihak menolak untuk berunding atau perundingan tidak mencapai kesepakatan maka perundingan bipartite dianggap gagal. Jika perundingan mencapai kesepakatan, maka dibuat perjanjian bersama yang mengikat dan menjadi hukum bagi pihak. Perjanjian bersama tersebut harus didaftarkan di Pengadilan Hubungan Industrial pada Pengadilan Negeri di wilayah para pihak yang mengadakan perjanjian bersama dan jika tidak dilaksanakan dilaksanakan oleh satu pihak, maka pihak yang dirugikan dapat mengajukan permohonan eksekusi kepada Pengadilan Hubungan Industrial pada pengadilan negeri di wilayah perjanjian bersama didaftarkan.

$$
\text { Mediasi hubungan kerja selanjutnya }
$$
disebut Mediasi adalah penyelesaian perselisihan hak, perselisihan kepentingan, perselisihan pemutusan hubungan kerja dan perselisihan antara serikat pekerja/serikat buruh hanya dalam satu perusahaan yang ditengahi oleh seseorang atau lebih mediator yang netral. Jadi mediasi ini merupakan lembaga yang berwenang menyelesaikan segala jenis perselisihan. Penyelesaian perselisihan melalui mediasi ini dilakukan di bidang ketenagakerjaan Kabupaten/Kota atau dengan kata lain yang menjadi mediator adalah pegawai Dinas Tenaga Kerja.

Pada instansi yang bertanggung jawab dibidang ketengakerjaan diangkat beberapa orang pegawai sebagai mediator yang berfungsi melakukan mediasi menyelesaikan perselisihan antara pengusaha dengan pekerja. (Sudjana, 2005:16)

Perbedaannya degan Undang-Undang Nomor 22 Tahun 1957 adalah jika sebelumnya setiap perselisihan wajib melalui proses perantaraan (mediasi) terlebih dahulu, maka berdasarkan Undang-Undang PPHI (selain perselisihan hak), pihak dinas tenaga kerja terlebih dahulu menawarkan kepada para pihak untuk dapat memilih konsiliasi atau arbitrase (tidak langsung melakukan mediasi), jika para pihak tidak menetapkan pilihan melalui konsiliasi atau arbitrase dalam waktu 7 (tujuh) hari, maka penyelesaian kasus akan dilimpahkan kepada mediator.

Dalam 7 (tujuh) hari setelah menerima permintaan penyelesaian perselisihan, mediator sudah harus mempelajari dan menghimpun informasi yang diperlukan, kemudian segera paling lambat pada hari kedelapan mengadakan pertemuan atau sidang mediasi. Untuk itu, mediator dapat memanggil saksi dan atau saksi ahli. 
Bila pengusaha dan pekerja dan serikat pekerja mencapai kesepakatan, kesepakatan tersebut dirumuskan dalam persetujuan bersama yang ditandatangani oleh para pihak yang berselisih diketahui oleh mediator.

Bila pengusaha dan pekerja tidak mencapai kesepakatan, dalam paling lama 14 hari setelah siding mediasi pertama, mediator harus sudah membuat anjuran tertulis tersebut, para pihak yang berselisih harus sudah menyampaikan pendapat secara tertulis kepada mediator menyatakan menyetujui atau menolak.

Bila pihak-pihak yang berselisih menerima anjuran mediator, kesepkatan tersebut dirumuskan dalam persetujuan bersama. Bila anjuran tertulis ditolak, maka pihak yang mengajukan gugatan kepada pengadilan $\mathrm{PHI}$ setempat. Untuk itu mediator menyelesaikan dokumen yang diperlukan dalam 5 hari kerja.

Dengan demikian seluruh proses mediasi diselesaikan paling lama dalam 40 hari kerja. Telah dijelaskan sebelumnya dalam perundingan bipartit, jika para pihak gagal menyelesaikannya secara bipartit maka para pihak harus mencatatkan hal tersebut dan kemudian instansi yang bertanggung jawab ketenaga kerjaan setempat wajib menawarkan kepada para pihak untuk menyepakati memilih penyelesaian melalui konsiliasi atau melalui arbitrase.

Konsiliator adalah masyarakat yang telah berpengalaman dibidang hubungan kerja dan menguasai peraturan perundang-undangan ketenagakerjaan yang ditunjuk oleh Menteri melakukan konsiliasi dan anjuran tertulis kepada pengusaha dan pekerja atau serikat pekerja menyelesaikan perselisihan kepentingan dan perselisihan pemutusan hubungan kerja. (Sudjana, 2005:16). Daftar konsiliator untuk satu wilayah kerja disediakan di kantor pemerintah yang bertanggung jawab dibidang ketenagakerjaan. Atas kesepakatan para pihak yang berselisih pengusaha dan pekerja atau serikat pekerja memilih dan meminta konsiliator dari daftar konsiliator setempat untuk menyelesaikan perselisihan mereka mengenai kepentingan atau PHK.

Arbitrase oleh Arbiter, berasal dari kata arbitrase (latin), arbitrage (Belanda dan Perancis), arbitration (Inggris), yang berarti kekuasaan untuk menyelesaikan sesuatu menurut kebijaksanaan atau damai oleh arbiter atau wasit.
Pasal 1 (1) Undang-Undang Nomor 30 Tahun 1999 tentang Arbitrase Alternatif Penyelesaian sengekta menyebutkan: Arbitrase adalah cara penyelesaian sengketa perdata diluar pengadilan yang didasarkan pada perjanjian arbitrase yang dibuat secara tertulis oleh para pihak yang bersengketa.

Sanusi bintang mengutip pendapat $R$. Subekti yang mengartikan arbitrase adalah penyelesaian atau pemutusan untuk seorang hakim atau para hakim didasarkan persetujuan bahwa para pihak akan tunduk atau menaati keputusan yang diberikan oleh hakin yang mereka pilih atau tunjuk tersebut. (Bintang dan Dahlan, 2000; 118)

Arbitrase adalah penyelesaian perselisihan oleh seorang atau tiga orang arbiter, yang atas kesepakatan para pihak yang berselisih diminta menyelesaikan perselisihan kepentingan, perselisihan PHK dan perselisihan antara serikat pekerja. Dalam hal pihak yang berselisih memilih 3 orang arbiter dan paling lambat 7 hari sesudah itu, kedua arbiter tersebut menunjuk arbiter ketiga sebagai ketua mejelis arbiter.

Dalam paling lama 30 hari sejak keputusan arbiter, salah satu pihak dapat mengajukan permohonan peninjauan kembali kepada Mahkamah Agung, hanya apabila: 1. Surat atau dokumen yang diajukan dalam pemeriksaan diakui atau terbukti palsu, 2. Pihak lawan terbukti secara sengaja menyembunyikan dokumen yang bersifat menentukan dalam pengambilan keputusan, 3. Keputusan arbitrase didasarkan pada tipu muslihat pihak lawan, 4. Putusan melampaui kewenangan arbiter, 5. Putusan bertentangan dengan peraturan prundangundangan.

Prosedur Penyelesaian Perselisihan terdapat dalam Pasal Undang-Undang Nomor 2 Tahun 2004 Tentang Penyelesaian Perselisihan Hubungan Industrial menyebutkan, yang redaksinya selengkapnya dikutip berikut ini:

1. Peselisihan hak,

2. Perselisihan kepentingan,

3. Peselisihan pemutusan hubungan kerja

4. Perselisihan antara serikat pekerja/serikat buruh hanya dalam satu perusahaan.

Adapun tahapan cara penyelesaian perselisihan lembaga industrial melalui Pengadilan Hubungan Industrial di Pengadilan Negeri setempat adalah dilakukan dengan cara: 
1. Pengajuan Gugatan

2. Proses Pemeriksaan,

Pengajuan gugatan perselisihan hubungan industrial diajukan kepada pengadilan hubungan industrial pada pengadilan negeri yang daerah hukumnya meliputi tempat pekerja/buruh bekerja. Pengajuan gugatan tersebut wajib dilampiri risalah penyelesaian melalui mediasi atau konsiliasi. Kalau tidak lampiri risalah penyelesaian melalui mediasi atau konsiliasi berkas dikembalikan kepada para pihak yang mengajukan gugatan.

Gugatan dapat dicabut penggugat sebelum tergugat member jawaban. Dalam keadaan ini maka proses peradilan selanjutnya tidak dilakukan. Hal ini dapat disebabkan adanya perdamaian antara tergugat dengan penggugat meskipun penggugat telah memasukkan gugatannya ke pengadilan.

Dengan adanya gugatan tersebut maka Pengadilan Negeri dalam 7 (tujuh) hari kerja menetapkan Majelis Hakim yang terdiri dari 1 (satu) orang hakim sebagai ketua majelis dan 2 (dua) orang hakim adhoc sebagai anggota majelis yang memeriksa dan memutus perselisihan. Dalam proses pemeriksaan perkara pada Pengadilan Hubungan Industrial pemeriksaan dapat dilakukan dengan dua cara yaitu: a). Pemeriksaan dengan acara biasa, dan b). Pemeriksaan dengan acara cepat.

Pada pemeriksaan dengan acara biasa

Majelis Hakim dalam 7 (tujuh) hari kerja menetapkan sidang, pemanggilan saksi atau saksi ahli. Saksi atau saksi ahli wajib memberikan kesaksian dibawah disumpah dan Hakim wajib merahasiakan semua keterangan yang diminta. Sidang pemeriksaan dengan acara biasa terbuka untuk umum, kecuali mejelis hakim menetapkan lain. Dalam hal salah satu pihak tidak menghadiri sidang tanpa alasan yang dapat dipertanggung jawabkan, majelis hakim dapat menetapkan hari sidang berikutnya.

Pelaksanaan hari sidang berikutnya selambat-lambatnya 7 (tujuh) hari terhitung sejak tanggal penundaan. Penundaan sidang karena salah satu atau para pihak diberikan sebanyakbanyaknya 2 kali penundaan. Dalam hal penggugat atau kuasa hukumnya yang sah setelah dipanggil secara patut tidak datang menghadap pengadilan pada sidang penundaan terakhir maka majelis hakim dapat memeriksa dan memutus perselisihan tanpa dihadiri tergugat. UndangUndang Nomor 2 Tahun 2004 Tentang Penyelesaian Perselisihan Hubungan Industrial juga menjelaskan bahwa setiap orang yang hadir dalam persidangan wajib menghormati persidangan.

Pemeriksaan dengan Acara Cepat, dilakukan apabila terdapat kepentingan para pihak dan atau salah satu pihak yang cukup mendesak yang harus dapat disimpulkan dari alasan-alasan permohonan dari yang berkepentingan, para pihak atau salah satu pihak dapat memohon kepada pengadilan hubungan industrial supaya pemeriksaan sengketa dipercepat ketua pengadilan negeri mengeluarkan penetapan tentang dikabulkan atau tidak dikabulkannya permohonan tersebut selama 7 (tujuh) hari kerja setelah diterimanya permohonan terhadap penetapan pemeriksaan dengan acara pemeriksaan cepat tidak digunakan upaya hukum.

Dalam hal permohonan dengan acara pemeriksaan cepat dikabulkan ketua pengadilan negeri dalam jangka 7 hari kerja, setelah dikeluarkannya penetapan menentukan Majelis Hakim, Hari, Tempat dan Waktu Sidang tanpa melalui prosedur pemeriksaan. Tenggang waktu untuk jawaban dan pembuktian kedua belah pihak masing-masing ditentukan tidak melebihi 14 hari kerja.

Sudikno Mertokusumo mengatakan putusan sela adalah putusan yang bukan putusan akhir atau disebut juga putusan antara, yang fungsinya tidak lain untuk memperlancar pemeriksaan perkara. (Mertokusumo, 2002: 222) Putusan sela ini menurut Pasal 185 Ayat (1) HIR (Oasal 196 Ayat (1) Rbg) sekalipun harus diucapkan didalam persidangan tidak dibuat secara terpisah, tetapi ditulis dalam berita acara persidangan.

Menurut M. Nur Rasaid putusan sela adalah putusan yang diadakan sebelum hakim memutus perkaranya, yaitu untuk memungkinkan atau mempermudah kelanjutan pemeriksaan perkara. (Rasaid, 2003: 49) Jadi putusan sela ini merupakan putusan yang diambil oleh hakim sebelum ia menjatuhkan putusan akhir.

Dalam hubungannya dengan Peradilan Hubungan Industrial maka keberadaan putusan ini adalah: 
a. Apabila dalam persidangan pertama secara nyata-nyata pihak pengusaha terbukti tidak melaksanakan kewajibannya membayar upah dan hak-hak yang biasa di terima pekerja, hakim ketua sidang harus segera menjatuhkan putusan sela berupa perintah kepada pengusaha untk melaksanakan kewajibannya kepada pekerja/buruh,

b. Putusan sela dapat dijatuhkan pada hari persidangan itu juga atau pada hari persidangan kedua,

c. Dalam hal selama pemeriksaan sengketa masih berlangsung dan putusan sela tidak juga dilaksanakan oleh pengusaha hakim ketua sidang memerintah sita jaminan dalam sebuah penetapan Pengadilan Hubungan Industrial,

d. Putusan sela dan penetapan pengadilan hubungan industrial tidak dapat diajukan perlawanan dan atau tidak dapat digunakan upaya hakim.

Putusan Akhir, dilakukan pada setiap putusan yang dijatuhkan oleh hakim dalam perkara hubungan industrial harus mempertimbangkan hukum, perjanjian yang ada, kebiasaan dan keadilan. Majelis hakim wajib menyelesaikan selambat-lambatnya 50 (lima puluh) hari kerja sejak sidang pertama. Putusan pengadilan hubungan industrial mengenai perselisihan hak dan perselisihan pemutusan hubungan kerja dapat diajukan kasasi ke Mahkamah Agung dalam waktu 14 (empat belas) hari kerja.

Putusan pengadilan hubungan industrial ditandatangani oleh hakim, Hakim Ad. Hoc dan panitra pengganti. Panitra pengganti hubungan industrial selambat-lambatnya menyampaikan pemberitahuan putusan kepada pihak yang tidak hadir dalam sidang.

Undang-Undang Nomor 2 Tahun 2004

Tentang Penyelesaian Perselisihan Hubungan Industrial merupakan rangkaian dari UndangUndang yang mengatur kedudukan dan kekuasaan Peradilan di Negara Republik Indonesia. Selain itu undang-undang tersebut juga merupakan lanjutan yang melengkapi Undang-Undang Mahkamah Agung Nomor 14 Tahun 1985 Tentang Mahkamah Agung yang selanjutnya diubah dengan UndangUndang Nomor 5 Tahun 2004.

Dengan lahirnya Undang-Undang Nomor 2 Tahun 2004, setiap lingkungan peradilan yang disebut dalam Pasal 10 Nomor 4 Tahun 2004 Tentang Kekuasaan Kehakiman yang berbunyi:

1. Kekuasaan kehakiman dilakukan oleh sebuah Mahkamah Agung dan badan peradilan yang berada dibawahnya dan oleh sebuah mahkamah konstitusi.

2. Badan peradilan yang berada dibawah mahkamah agung meliputi badan peradilan dalam lingkungan peradilan umum, peradilan agama, peradilan militer dan peradilan tata usaha.

Hal lainnya yang diatur secara khusus dalam undang-undang penyelesaian perselisihan hubungan industrial adalah ketentuan mengenai hakim ad Hoc dan kepanitraan dalam pengadilan hubungan industrial. Selain itu terdapat pula halhal yang baru yang tidak lazim, dalam undangundang penyelesaian perselisihan hubungan industrial ini seperti misalnya terdapat ketentuan pembebasan biaya perkara dan juga pembebasan biaya eksekusi bagi gugatan yang nilainya dibawah Rp. 150 juta. Ketentuan mengenai pembebasan biaya perkara ini seharusnya dipertimbangkan dengan matang, karena harus diatur alokasi pembiayaan yang tidak sedikit bagi pengadilan hubungan industrial dalam memproses suatu perkara.

\section{SIMPULAN}

Mekanisme penyelesaian perselisihan hubungan kerja atau hubungan industrial pada dasarnya diselesaikan di Pengadilan Hubungan Industrial (PHI). Sebelum mencapai tahap atau tingkatan Pengadilan Hubungan Industrial (PHI) dapat ditempuh tahap-tahap awal atau alternatif yang terdiri dari: lembaga, bipartite, mediasi, konsilisai dan abitrase. Lembaga bipartit adalah suatu bentuk perundingan antara pekerja buruh atau serikat buruh dengan pengusaha untuk menyelesaikan perselisihan hubungan kerja.

Mediasi adalah penyelesaian perselisihan hak, perselisihan kepentingan, perselisihan pemutusan hubungan kerja dan perselisihan antara serikat pekerja/serikat buruh hanya dalam satu perusahaan yang ditengahi oleh seseorang atau lebih mediator yang netral. Konsiliasi adalah masyarakat yang telah berpengalaman dibidang hubungan kerja dan menguasai peraturan perundang-undangan ketenagakerjaan yang ditunjuk oleh Menteri melakukan konsiliasi dan anjuran tertulis kepada pengusaha dan pekerja 
atau serikat pekerja menyelesaikan perselisihan kepentingan dan perselisihan pemutusan hubungan kerja. Arbitrase adalah penyelesaian perselisihan oleh seorang atau tiga orang arbiter, yang atas kesepakatan para pihak yang berselisihan diminta menyelesaikan perselisihan kepentingan, perselisihan $\mathrm{PHK}$ dan perselisihan antara serikat pekerja.

Proses hukum atau tahapan dan cara penyelesaian hukum pemutusan hubungan kerja yaitu: Proses pengajuan gugatan di pengadilan Hubungan Industrial di wilayah hukum pengadilan Negeri setempat. Proses pemeriksaan perkara pada Pengadilan Hubungan Industrial. Putusan oleh majelis hakim Pengadilan Hubungan Industrial yang menyatakan hubungan kerja antara perusahaan dengan karyawannya putus karena pemutusan hubungan kerja dan menghukum perusahaan yang digugat untuk membayar hak-hak karyawannya, sesuai ketentuan Pasal 156 Ayat (1), (2), (3) dan (4) UndangUndang Nomor 13 Tahun 2003.

\section{DAFTAR PUSTAKA}

Sunggono, B., 1997, "Metodologi Penelitian Hukum”, PT. Raja Grafindo Persada, Jakarta.

Sudjana, E., 2005, "Bayarlah Upah Sebelum Keringatnya Mengering”, PPMI, Jakarta.

Husni, L., 2000, "Pengantar Hukum Ketenagakerjaan Indonesia”, PT. Raja Grafindo Persada, Jakarta.

2000, “Dasar-Dasar Hukum
$\begin{aligned} & \text { Perburuhan”, PT. Raja Grafindo Persada, } \\ & \text { Jakarta. }\end{aligned}$
2004, "Penyelesaian Perselisihan Hubungan Industrial Melalui Pengadilan dan Diluar Pengadilan", PT. Raja Grafindo Persada, Jakarta.

2010, Hukum Ketenagakerjaan
$\begin{aligned} & \text { Indonesia", PT. Raja Grafindo Persada, } \\ & \text { Jakarta. }\end{aligned}$

Mulyadi, L dan Agus S., 2011, "Penyelesaian Perkara Pengadilan Hubungan Industrial dalam Teori dan Praktik", PT. Alumni, Bandung.

Simorangkir, J.C.T, "Hukum Ketenagakerjaan di Indonesia”, Pustaka Yuridis, Jakarta.

Poerwadarminta, W.J.S., 2004, “Kamus Umum Bahasa Indonesia”, Penerbit Balai Pustaka, Jakarta.
Asyhadi, Z., 2007, "Hukum Kerja, Hukum Ketenagakerjaan Bidang Hubungan Kerja” Raja Grafindo Persada, Jakarta.

\section{B. Peraturan Perundang-Undangan}

Undang-Undang Nomor 2 Tahun 2004 Tentang Penyelesaian Perselisihan Hubungan Industrial

KUH Perdata

Undang-Undang Nomor 13 Tahun 2013 tentang Ketenagakerjaan 